\title{
USO DA TERRA E QUALIDADE AMBIENTAL URBANA: UMA PROPOSTA DE LEGENDA PARA MAPEAMENTO
}

João Carlos Nucci*

Universidade Federal do Paraná

Simone Valaski* ${ }^{*}$

Universidade Federal do Paraná

\section{Laura Freire Estêvez ${ }^{\star \star \star}$}

Universidade Federal do Paraná

\author{
Emerson Luis Tonetti ${ }^{\star \star \star *}$ \\ Instituto Federal do Paraná
}

\begin{abstract}
Resumo: A paisagem urbana apresenta uma variedade de estruturas e dinâmicas fortemente determinadas pelo uso e pela cobertura da terra, constituintes fundamentais na definição da qualidade ambiental urbana. 0 ordenamento do uso da terra, nas zonas urbanas, é fornecido principalmente pelas leis municipais de uso e ocupação do solo, que apresentam alto grau de complexidade dificultando a participação popular nas decisões de planejamento. 0 trabalho apresenta uma proposta de hierarquização dos usos da terra conforme suas potencialidades em aumentar ou diminuir a qualidade ambiental. Foram utilizadas revisão de bibliografia e legislação de zoneamento urbano como subsídios para as inferências sobre a qualidade ambiental relacionada a cada uso da terra. As centenas de diferentes usos da terra, identificados nas leis de zoneamento urbano, foram organizados na forma de uma legenda, para mapeamento em escala do lote, constituída por 15 níveis de qualidade ambiental, conforme as características de uso e de porte do estabelecimento. A legenda proposta fornece importante subsídio para o mapeamento da qualidade ambiental urbana e para a participação popular no planejamento, já que simplifica o tratamento complexo encontrado na legislação de zoneamento urbano.
\end{abstract}

Palavras-chave: Planejamento da Paisagem. Ecologia Urbana. Classificação dos usos da terra.

\section{LAND USAGE AND URBAN ENVIRONMENTAL QUALITY: A PROPOSAL FOR A MAPPING KEY.}

Abstract: Urban landscapes feature a variety of structures and dynamics strongly determined by the land use and coverage, fundamental components of the urban environmental quality definition. The disposition of land use in urban areas is established, mainly, by Municipal Laws on the land use and occupation, which present a high degree of complexity, making difficult the people's participation in the planning decisions. This work brings forward a proposal for the creation of a hierarchy for the land uses, based on its potential to increase or decrease the environmental quality. We did a bibliography and urban zoning legislation review as a subsidy for the inferences about the environmental quality related to each land use. The hundreds of land uses identified in the urban zoning legislation were organized under the format of a "key" for a scaled mapping of the plot, distributed through 15 environmental quality levels, depending on the usage characteristics and size of the establishment. The proposed "key" gives an important subsidy to the mapping of the urban environmental quality and the people's participation in the planning, since it simplifies the complexity of the approach found in the urban zoning legislation.

Keywords: Landscape Planning. Urban Ecology. Land Use Classification.

\section{USO DE LA TIERRA Y CALIDAD AMBIENTAL URBANA: UNA PROPUESTA DE LEYENDA DE MAPEO}

Rsumem: El paisaje urbano presenta una variedad de estructuras y dinámicas fuertemente determinadas por el uso y la cobertura del suelo, componentes fundamentales en la definición de la calidad ambiental urbana. La planificación del uso del suelo en las zonas urbanas se realiza principalmente por las leyes municipales de uso y ocupación del suelo, que son muy complejas y dificultan la participación popular en las decisiones de planificación. El documento presenta una propuesta de jerarquización de los usos de la tierra de acuerdo con su potencial para aumentar o disminuir la calidad ambiental. La revisión bibliográfica y la legislación de zonificación urbana se utilizaron para respaldar las inferencias sobre la calidad ambiental relacionada con cada uso de la tierra. Los cientos de diferentes usos del suelo identificados en las leyes de zonificación urbana se organizaron en forma de un subtítulo para mapear la escala de la parcela, que consta de 15 niveles de calidad ambiental, de acuerdo con las características de uso y tamaño del establecimiento. El subtítulo propuesto proporciona información importante para mapear la calidad ambiental urbana y la participación popular en la planificación, ya que simplifica el tratamiento complejo que se encuentra en la legislación de zonificación urbana.

Palabras clave: Planificación del paisaje. Ecología urbana. Clasificación de usos del suelo.

*Doutor em Geografia. Professor do Departamento de Geografia da Universidade Federal do Paraná. Endereço: Centro Politécnico, C.P. 19.001, CEP 81.531-970 Curitiba/PR. ORCID: http://orcid.org/0000-0003-1130-925X. E-mail: jcnucci@gmail.com

**Doutora em Geografia. Professora do Setor de Educação Profissional e Tecnológica da Universidade Federal do Paraná. Endereço: Centro Politécnico, Rua Dr Alcides Vieira Arcoverde, 1225, CEP 81.520-260 Curitiba/PR. ORCID: https://orcid.org/0000-0002-9849-500X E-mail: valaski.geo@gmail.com

**Doutora em Geografia. Pós-doutoranda no Programa de Pós-graduação em Geografia. Depto. de Geografia da Universidade Federal do Paraná. Endereço: Centro Politécnico, C.P. 19.001, CEP 81.531-970 Curitiba/PR. ORCID: http://orcid.org/000-0001-5747-7203 E-mail: laurafreire.geo@gmail.com

***Doutor em Geografia. Professor no Instituto Federal do Paraná campus Paranaguá, eixo tecnológico de meio ambiente, programa de pós-graduação em Ciência Tecnologia e Sociedade. Endereço: Rua Antônio Carlos Rodrigues, 453, bairro Porto Seguro, Paranaguá, Paraná, CEP 83.215-750. ORCID: https://orcid.org/0000-0003-3325-0615 E-mail: emerson.tonetti@ifpr.edu.br 


\section{Introdução}

A concentração crescente da população urbana e a expansão vertical e horizontal das cidades levam a uma intensificação dos problemas de ordem social, econômica e ambiental, de interesse não só dos administradores e políticos, mas de toda a sociedade, requerendo uma participação efetiva de todos no trato dessas questões.

Apesar de sua modesta ocupação territorial no planeta, as regiões urbanas vêm provocando substanciais impactos ambientais locais, regionais e globais. Esses incluem destruição e modificações de habitats, construção de habitats artificiais, mudanças na biodiversidade, no processo de seleção natural, no microclima, na dinâmica hidrológica, aumento da poluição, da compactação do solo e declínio dos serviços ecossistêmicos, entre outros (FRANCIS; CHADWICK, 2013, p. 15).

Problemas ambientais podem ser causados por padrões espaciais (cobertura da terra) e atividades humanas (uso da terra) que, de acordo com suas características, podem alterar as funções do ambiente natural e afetar os processos físicos. Pauleit e Breuste (2011) afirmam que o uso e a cobertura da terra são componentes importantes que entram na composição da estrutura das paisagens, interferindo em suas dinâmicas e, consequentemente, em suas qualidades.

Portanto, o controle do uso e da cobertura da terra nas cidades é de fundamental importância para a qualidade ambiental urbana. Esse controle geralmente é realizado por leis federais, estaduais e municipais, sendo as leis de zoneamento municipais ou Leis de Uso e Ocupação do Solo (LUOS) as que concentram a legislação das outras esferas de poder e agem mais diretamente nas zonas urbanas do município.

Todavia, textos, quadros e mapas característicos das LUOS são muito complexos para o entendimento do cidadão leigo e apenas tangenciam as questões relacionadas com a qualidade ambiental urbana, sendo necessária uma tradução simplificadora do conteúdo dessas leis e que relacione as tipologias de uso e de cobertura da terra com níveis de qualidade ambiental.

Entre as diversas abordagens dos estudos que tratam da qualidade ambiental urbana, podem-se destacar aquelas relacionadas com o Planejamento da Paisagem, um instrumento legal, com origens alemãs, que apresenta como um dos seus objetivos a definição de recomendações sobre metas de qualidade ambiental e sobre critérios para Avaliação de Impacto Ambiental (HAAREN, et al., 2008). O Planejamento da Paisagem representa um instrumento central de planejamento visando à conservação da natureza, em áreas urbanizadas ou não, tendo o "objetivo de salvaguardar a capacidade dos ecossistemas e o potencial recreativo da paisagem como partes fundamentais para a vida humana" (NUCCl, 2008, p.9). Assim, o Planejamento da Paisagem deve contribuir para a renovação das áreas urbanas salvaguardando e desenvolvendo as funções ecológicas e estruturais dos espaços livres (parques e outras áreas verdes), flora e fauna típicas, suprimento de ar fresco para as áreas construídas, proteção e reabastecimento da água subterrânea, renaturalização de corpos hídricos, ampliação das áreas cultivadas, redução das áreas pavimentadas, criação de áreas de repouso e recomendações sobre o design das áreas construídas (HAAREN et al., 2008).

O Planejamento da Paisagem exige a participação popular, assim, a elaboração de mapas em escalas mais detalhadas e com legendas claras e objetivas, que evidenciem a estrutura e dinâmica da paisagem e as consequências advindas destas interações subsidiam a participação do cidadão. É oportuno destacar que no Brasil existe a preocupação de que os Planos Diretores dos municípios devam utilizar informações com linguagem simplificada, para facilitar a participação dos atores sociais (BRASIL, 2006). Souza (2002) propõe uma "pedagogia urbana" destacando a "tradução" de políticas públicas em linguagem acessível. Entretanto, nem sempre as informações estão disponíveis e o que geralmente se encontra, por exemplo, nos sites das prefeituras na internet, é uma grande quantidade de informações que se configuram mais como um banco de dados do que como uma ferramenta para a promoção da participação popular nas tomadas de decisões (VALASKI, 2013).

Em se tratando de uso da terra, as principais informações podem ser encontradas nas leis municipais de zoneamento ou LUOS (Leis de Uso e Ocupação do Solo), na forma de texto e de mapas de zoneamento, com informações muito complicadas para o entendimento e manuseio do público em geral. Assim, é preciso que pesquisas contribuam com a proposição de subsídios cartográficos que representem a estrutura das paisagens tornando possível o entendimento, também pela comunidade leiga, dos processos e das consequências das decisões tomadas sobre essas paisagens.

Acredita-se, portanto, que a elaboração de legendas completas e bem explicadas, em escala de maior detalhe, com a utilização de esquemas, fotos e textos objetivos e de uma linguagem menos complexa, possa trazer um maior entendimento da população sobre a dinâmica da paisagem e, consequentemente, essa possa se 
posicionar em relação às ações do poder público no desenvolvimento do município.

Essas questões foram abordadas no método desenvolvido por Valaski (2013) e aprimorado por Nucci, et al. (2014) que trouxe um avanço nos estudos de avaliação da qualidade ambiental urbana desenvolvidos por Nucci $(1996,2008)$, por permitir de modo mais rápido e descomplicado, realizar inferências sobre a dinâmica da paisagem e sua qualidade, por meio de sua estrutura, considerando apenas a cobertura, e não o uso da terra, que pode ser descrita com a análise de imagens de satélite, em escala mais detalhada e de fácil acesso para a população. Como complemento, este trabalho colocou o foco no uso da terra, como importante indicador das condições ecológicas urbanas e que requer uma caracterização mais ampla de suas funcionalidades ecológicas.

Portanto, o objetivo da pesquisa foi o de organizar uma legenda para o mapeamento do uso da terra em escala de detalhe (entre 1:3.000 e 1:5.000), bem como apresentar as implicações desses usos na qualidade ambiental, com o intuito de fornecer subsídios para a espacialização dessas informações e para a participação popular no desenvolvimento urbano.

\section{Revisão bibliográfica}

Os estudos que pretendem entender a dinâmica da paisagem são complexos, demorados e onerosos, e nem sempre podem ser realizados e finalizados na urgência que exige o desenvolvimento, principalmente aquele que ocorre nas áreas urbanizadas. São estudos de difícil compreensão para quem não é especialista no assunto, o que impossibilita a participação de outros profissionais bem como da comunidade envolvida, exigência fundamental do Planejamento da Paisagem.

Pode-se considerar, portanto, como uma alternativa a essas dificuldades, a possibilidade de se inferir, ou seja, de se deduzir pelo raciocínio, a dinâmica' da paisagem com base em sua estrutura ${ }^{2}$, que pode ser considerada como mais facilmente perceptível a todos, e assim, subsidiar o prognóstico, ou seja, os estudos das consequências (impactos positivos e negativos) dos usos da terra, transformando o diagnóstico e o prognóstico da paisagem em estudos mais compreensíveis por todos.

Para Hough (1995), os diferentes tipos de paisagem são consequência das forças que lhe dão origem. Assim, pode-se dizer que a estrutura/forma da paisagem reflete as forças naturais e antrópicas que a originaram, porém, em uma visão sistêmica, deve-se também considerar as ações da estrutura sobre a dinâmica, ou seja, que essas forças (dinâmica), em um processo complexo e contínuo de ação e reação, modificam e são modificadas pela estrutura da paisagem ao longo de sua evolução (transformação temporal ou diacrônica). Assim, afirmase ser possível com base na estrutura fazer inferências quanto à dinâmica de uma paisagem, como ilustra a figura 1.
' $\mathrm{Na}$ literatura também são encontrados os termos processo, função e funcionamento com omesmo significado do termo dinâmica.

${ }^{2} \mathrm{Na}$ literatura são encontrados os termos constituição, elementos, forma e padrão com o mesmo significado do termo estrutura. 
Figura 1 - Ilustração esquemática sobre a possibilidade de se inferir (deduzir pelo raciocínio) a dinâmica da paisagem com base em sua estrutura.

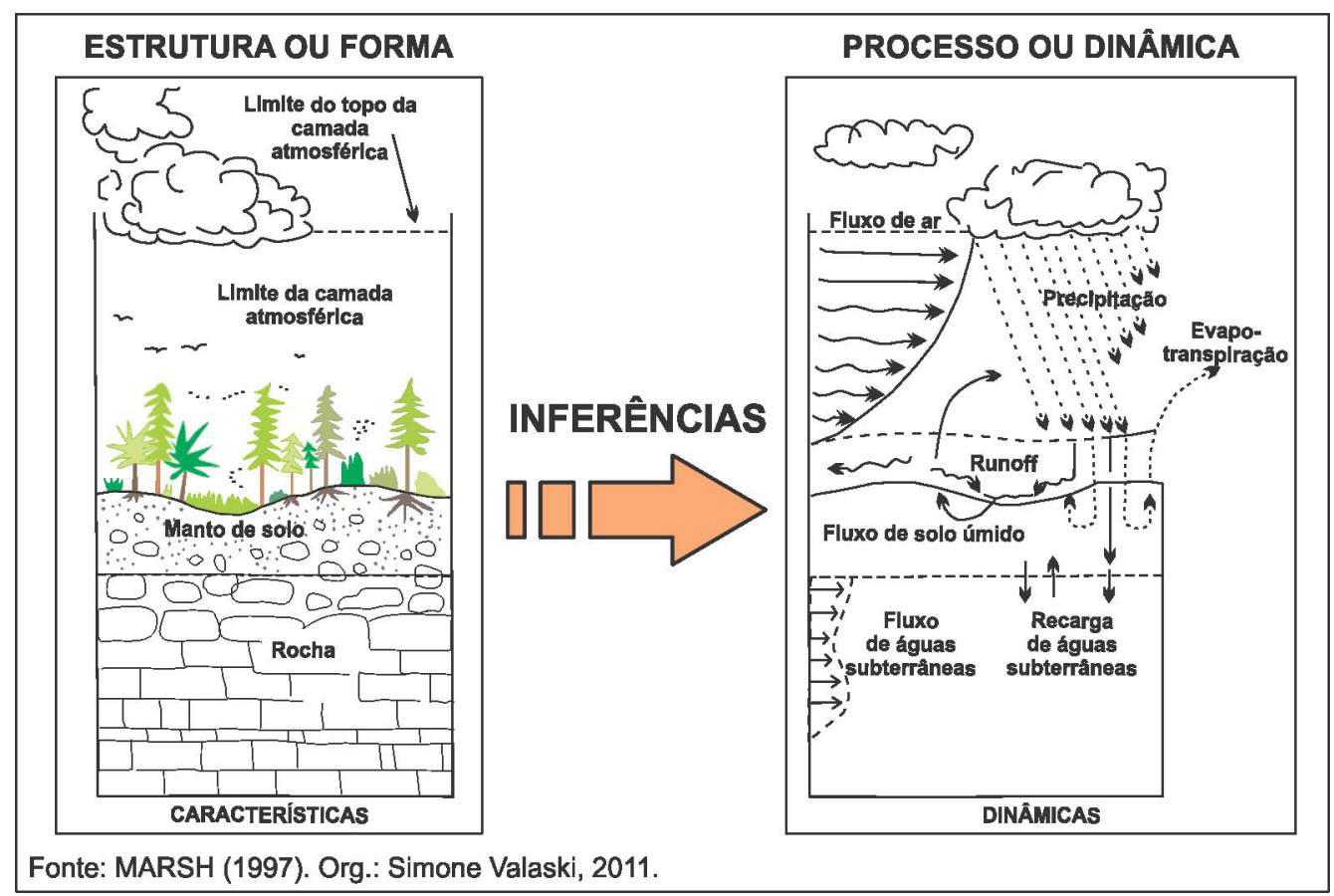

O crescimento urbano não espera por estudos demorados e onerosos e segue transformando, com grande intensidade e velocidade, as paisagens. Isso dá força ao artifício da inferência com o intuito de se prever as alterações na dinâmica com base nas modificações da estrutura da paisagem. Nucci (1996) utilizou de inferências para avaliar a qualidade ambiental no Distrito de Santa Cecília (MSP). Com a falta de dados que pudessem fornecer, por exemplo, o grau e a distribuição espacial e temporal da poluição atmosférica em todo o Distrito e em uma escala da ordem de 1:10.000, o autor realizou o levantamento em campo de todos os usos, lote por lote, existentes na área, na escala de 1:2.000 e, posteriormente, inferiu que os usos como, por exemplo, posto de gasolina, funilaria, mecânicas, estacionamentos, entre outros, seriam considerados como "potencialmente poluidores", o que diminuiria a qualidade ambiental nos locais que abrigavam esses usos, bem como nos seus arredores.

Em regiões urbanizadas, a estrutura da paisagem construída pelo ser humano afeta o funcionamento do ecossistema. A urbanização afeta a produtividade primária, a ciclagem de nutrientes, a função hidrológica e as dinâmicas ecossistêmicas, devido às modificações dos processos climáticos, hidrológicos, geomorfológicos e bioquímicos, bem como as interações bióticas. 0 uso da terra e seus impactos ecológicos são uma função dos padrões espaciais das atividades humanas e habitats naturais, que afetam os processos ecológicos e socioeconômicos em várias escalas (ALBERTI, 2008).

Segundo Pauleit e Breuste (2011, p. 20), atenção deve ser dada para as dinâmicas de uso e de cobertura da terra devido aos seus impactos ambientais, salientandose seus papeis como indicadores chave dos processos ecossistêmicos na cidade.

O termo "uso da terra" pode ser definido conforme a utilização de acordo com os aspectos socioeconômicos e o termo "cobertura da terra" de acordo com o padrão físico com base na heterogeneidade estrutural (CADENASSO, et al., 2007). Exemplos de uso da terra seriam o residencial, o comercial, o industrial, etc., e de cobertura da terra os diferentes tipos de vegetação, água, rocha nua, construções criadas pelo homem, etc.

No meio urbano, há tipos estruturais (Urban structural types) ou unidades morfológicas (urban morphology units and types - UMTs), que são produtos do passado e do presente causados pelo uso da terra, podendo ser distinguidos por padrões característicos de edificações e de espaços livres (PAULEIT; DUHME, 2000, p. 2).

Assume-se que cada UMT apresente feições físicas características e distinguíveis de acordo com as atividades humanas que elas acomodam, ou seja, o uso da terra. Propriedades físicas e as atividades humanas são assumidas como fatores chave que determinam as 
propriedades ecológicas das áreas urbanas e estudos sugerem que a distinção dos UMTs na escala entre o nível de cidade e o dos lotes fornece uma base adequada para a análise espacial das cidades (GILL et al., 2008, p. 211).

Sobre estudos relacionados com o uso da terra, Berke, et al. (2006) colocam que modelos urbanísticos recentes têm surgido na tentativa de conter os impactos, principalmente do crescimento da urbanização sobre as zonas suburbanas. Esses modelos buscam promover um desenvolvimento compacto (aumento das densidades populacionais e de edificação nos centros urbanos), com mistura de usos e com caminhos amigáveis para os pedestres, o que estimularia uma mudança no modo de locomoção (a troca dos automóveis pelo caminhar, pela bicicleta e pelo transporte coletivo), favorecendo também um espírito de comunidade com o aumento das possibilidades de interação entre as pessoas (BERKE, et al., 2006).

Mesmo autores mais voltados para as Ciências Biológicas, tais como Richard Forman, parecem concordar com o desenvolvimento compacto e a mistura de usos na cidade, quando destacam que:

Um dos princípios mais importantes do planejamento ambiental urbano é integrar harmonicamente diversos usos rompendo com o zoneamento segregado. Tom Turner critica fortemente os usos exclusivos em várias áreas afırmando que isso não seria bom para o ambiente. Turner comenta que se os estudantes ficam isolados no campus, faltam-Ihes lojas, entretenimentos, empregos e diversidade de moradias e que se os locais de trabalho ficam isolados dos locais de moradia, todos somos obrigados a usar $\mathrm{o}$ sistema de transporte. (TURNER, $1998^{3}$ apud FORMAN, 2014, p. 334).

Forman afirma que um centro comercial, muitas vezes com edifícios com lojas no térreo, escritórios no segundo andar e residências nos outros, pode combinar várias atividades, sendo acessível a pé por residentes das redondezas e fornecendo um bom exemplo de padrões de uso misto, onde serviços, lojas de varejo, restaurantes estão próximos ou misturados com as residências, promovendo um padrão que limita a emissão de poluentes pelos meios de transporte (FORMAN, 2014, p. 334).

Pauleit e Breuste (2011, p. 19) concordam com essa visão e afirmam que o planejamento tem frequentemente separado as funções urbanas, tais como morar, trabalhar

${ }^{3}$ TURNER, T. Landscape Planning and Environmental Impact Design. Londres: UCL Press, 1998. 256p e recrear, e tem conectado esses usos por uma extensa infraestrutura de transporte, que aumenta a demanda por automóveis. Por outro lado, há proposições de planejamento urbano que estimulam o uso misto em cidades compactas.

Mota (1999) concorda com essas colocações ao afirmar que "(...) uma mistura ordenada de usos residencial, comercial, de trabalho e lazer, facilitará a realização de várias atividades com um número menor de viagens" (MOTA, 1999, p. 226).

Por outro lado, Nucci (1996) demonstrou que a mistura de usos pode ser prejudicial para a qualidade ambiental, pois colocar lado a lado residências e usos com alta potencialidade para aumentar a poluição, tais como postos de combustíveis, funilarias, mecânicas, etc., não pode ser considerado aceitável em um bom planejamento. Mota (1999) afirma que a ordenação destes usos deve levar em consideração outros aspectos, de forma que os mesmos sejam compatíveis. $\mathrm{E}$, seria bom destacar que Turner (op cit.), nessa questão, ainda afirma que o objetivo é permitir usos múltiplos de boa vizinhança e colocar os de má vizinhança em zonas industriais. Portanto, a questão seria discernir os usos de boa e de má vizinhança na zona urbana.

Mesmo Forman, que acima se mostra favorável à mistura de usos, constata que alguns prédios altos, que no piso inferior apresentam comércio de alimentos (bares, restaurantes, etc.), são importantes ecologicamente devido a considerável quantidade de resíduos de alimento que atraem pestes como ratos, camundongos, baratas eformigas. Acrescenta que hotéis e centros de convenção também apresentam restos de alimentos e pestes e, que nessas áreas, em ruas com lojas e comércio de alimentos e com a alta densidade de residentes, pode haver numerosas sacolas com lixo espalhadas, sem falar das mercearias e supermercados, concluindo que os resíduos de alimentos e pestes são desafios intermináveis da maioria das cidades (FORMAN, 2014, p. 328).

Numerosos pequenos centros de compras servem os bairros residenciais e estão espalhados pela área metropolitana: restaurantes, bares, padarias, farmácias, posto de gasolina, etc. Se estão a uma distância alcançável a pé, a situação pode reduzir os níveis de hidrocarbonetos, metais pesados, particulados e gases do efeito estufa provenientes dos veículos. Contudo, em longo prazo, posto de gasolina pode ter vazamento de tanques e tubulações ocasionando poluição do solo e da água por hidrocarbonetos e a maior parte dos poluentes não gasosos na superfície são lavados pela chuva para dentro do sistema de drenagem e para os corpos d'água (FORMAN, 2014, p. 332). 
O uso comercial geralmente se encontra em avenidas bem movimentadas e esse tipo de uso pode conter área para estacionamento para os compradores, entregas de caminhão, remoção de resíduos, etc. o que ocasiona ruído, lixo, ruas congestionadas e outros poluentes que prejudicam as residências próximas (FORMAN, 2014, p. 334).

Portanto, os mesmos autores que valorizam a compactação das cidades (adensamento de pessoas e de edificações), por outro lado, enfatizam as consequências negativas para a qualidade ambiental oriundas desse adensamento e mistura de usos.

Quanto às áreas industriais, parece não haver muita controvérsia em relação as suas capacidades de causarem degradação ambiental. Segundo Mota (1999), muitos resíduos industriais já foram analisados, conhecendo-se as características dos principais. E essas informações "(...) servem como indicação das indústrias que merecerão maiores cuidados quando da sua localização" (MOTA, 1999, p. 189).

As indústrias podem variar de tamanho e de concentração das plantas. Durante a produção industrial grandes entradas (inputs) e saídas (outputs) de energia e matéria determinam as condições ecológicas. As plantas das indústrias contem edifícios de manejo e de produção, grandes pátios e estacionamentos asfaltados com acesso para caminhões, área de acúmulo de rejeitos, armazenamento de matéria-prima e área vegetada para expansão futura. Estradas e linhas férreas podem estar por perto para facilitar o acesso e o escoamento dos produtos. A acumulação de resíduos é um problema central: escória, produtos orgânicos tóxicos, ácidos, metais pesados, etc. (FORMAN, 2014, p. 336 e 337).

Para Mota (1999, p. 201), listas que classificam as indústrias em função do potencial de poluição são úteis no processo de disciplinamento do uso do solo, como, por exemplo, a classificação de indústrias por emissão de poluentes que, segundo a Agência de Proteção do Meio Ambiente dos Estados Unidos, podem ser divididas em 3 classes: indústria leve (madeira, móveis, etc.), indústria pesada (produtos alimentícios, máquinas e instrumentos, etc.), indústria crítica (petróleo, etc.), posições que variam dependendo do poluente considerado.

Quadros existentes no Plano Urbanístico Básico do Município de São Paulo ${ }^{4}$, citado por Mota (1999, p. 202 a 206), organizam as indústrias de acordo com o potencial poluidor da atmosfera, em: grande, médio, pequeno e leve. Indústrias com potencial grande seriam, por exemplo, as de fabricação de celulose, cal, cimento,

4SÃO PAULO. Plano Urbanístico Básico do Município de São Paulo. Prefeitura do MSP, Grupo Executivo do Planejamento, São Paulo, 1969. siderurgia e de abate de animais; as de potencial médio seriam, por exemplo, as de fabricação e elaboração de vidro, preparação de conservas de pescado; as de potencial pequeno, fabricação de telhas, tijolos, funilaria, reparação de máquinas, fabricação de açúcar; e as de potencial leve seriam, por exemplo, as de fabricação de calçados, editora e gráfica, fabricação de bebidas, fiação, fabricação de móveis de madeira.

Mota (1999, p. 198) ressalta que "as indicações destes quadros são muito úteis na fase de planejamento. No entanto, para cada classe de indústria existe uma grande variedade de processos, mais ou menos poluidores" e afirma que "Essas classificações devem ser usadas com cautela, apenas como indicações gerais, úteis na fase de planejamento. Na fase de implantação (...) deve ser feito um estudo detalhado do processo (...)" (MOTA, 1999, p. 207).

Um uso não industrial, mas que requer análises mais aprofundadas seria o dos cemitérios que nos EUA e na Europa podem ser considerados benéficos para o ambiente e para a sociedade. Forman afirma que o cemitério pode servir também como área de lazer para a vizinhança e que os mesmos apresentam possibilidades de conter uma importante biodiversidade, todavia, produtos químicos como formaldeído, um carcinogênico, podem poluir o solo e a água subterrânea (FORMAN, 2014, p. 357).

Tanto para a poluição atmosférica quanto para a poluição sonora, uma das principais medidas de prevenção seria o afastamento das fontes poluidoras das áreas receptoras. Mota (1999) afirma que

\footnotetext{
O disciplinamento do uso do solo tem um papel muito importante no controle preventivo da poluição do ar, uma vez que a localização adequada das fontes de poluição atmosférica, com base nas características ambientais, contribui para evitar os efeitos indesejáveis sobre as áreas receptoras sensíveis. (MOTA, 1999, p. 195).
}

"A ferramenta principal do planejador, após identificar as áreas mais favoráveis, do ponto de vista climático ou topográfico, é o afastamento entre as fontes poluidoras e as áreas receptoras" (MOTA, 1999, p. 214). Mota afirma que "Através de afastamentos adequados podem ser minimizadas as concentrações de poluentes em áreas sensíveis" (MOTA, 1999, p. 214), considerando as "(...) áreas receptoras sensíveis - zonas residenciais, escolas, hospitais, áreas de lazer, entre outras" (MOTA, 1999, p. 197).

Na Rússia há zonas de proteção sanitária que variam de $50 \mathrm{~m}$ a $1.000 \mathrm{~m}$, em função do potencial poluidor das indústrias, sendo as de $50 \mathrm{~m}$, por exemplo, carpintaria, 
marcenaria, fabricação de roupas, de calçados, de doces e padarias. (MOTA, 1999, p. 214). O Plano Urbanístico Básico do Município de São Paulo (op cit.) sugeriu a adoção de Faixas Sanitárias de Proteção, entre as fontes de poluição do ar e áreas de habitações, saúde, educação e de recreação, sendo que para as indústrias potencialmente grandes poluidoras do ar a faixa seria de $1.500 \mathrm{~m}$ e para indústrias não poluidoras, a faixa seria de no mínimo 50m (MOTA, 1999, p. 218 e 219).

Portanto, a distribuição dos usos na zona urbana deve prever uma distância adequada entre as fontes de poluição e as áreas mais sensíveis. Uma medida, que parece não ser a ideal, foi sugerida por alguns autores, como Mota (1999) e Nucci (1996), que propuseram que entre o emissor e o receptor poderiam ser instalados usos menos sensíveis, como uma forma de separar usos incompatíveis: "por exemplo, entre indústrias com alto potencial de poluição acústica e uma zona residencial, podem ser colocadas outras indústrias não barulhentas, uma zona de uso comercial e de serviços, e uma área verde" (MOTA, 1999, p. 239). No caso de aeroportos, há um zoneamento com base na previsão de exposição ao barulho, e normativas chegam a sugerir que cinturões verdes, uso agrícola, uso industrial e comercial, cemitério, feiras livres e lazer ao ar livre (praças e parques) poderiam ser posicionados em zonas com nível de incomodo sonoro potencialmente nocivo (MOTA, 1999, p. 247 a 249), o que pode até ser entendido como uma perversidade devido à exposição de pessoas a ruídos extremos.

Pode-se considerar que nem todos os usos apresentam potencial para ocasionar uma piora na qualidade ambiental. Forman chama a atenção para os parques que podem trazer muitos benefícios, tais como: recreação, saúde, educação, cultura, história; experiência com a natureza, estruturas pitorescas, variações nas cores/texturas/densidade das plantas; resfriamento, controle do vento, umidade, limpeza o ar, barreira contra ruído, luz, inundação e erosão; plantas, vegetação, animais, movimento da vida selvagem, biodiversidade, ecossistemas aquáticos, peixes; e valor das propriedades, turismo, e valores não monetários (FORMAN, 2014, p. 349).

Todavia, Barton e Tsourou (2000), em trabalho realizado para a Organização Mundial da Saúde, na busca de garantias de "Qualidade Ambiental" em "Cidades Saudáveis", reforçam a importância do planejamento da distribuição dos usos no meio urbano, deixando claro que existe uma distância mínima e uma máxima entre os diferentes usos e as áreas residenciais (FIGURA 2), o que evitaria a proximidade de usos incompatíveis ou inconvenientes, conforme prega o Estatuto da Cidade (BRASIL, 2001).

Figura 2 - Proposição de distâncias mínimas e máximas, em metros, entre a residência e os diferentes tipos de usos como uma medida para se garantir a qualidade ambiental em cidades saudáveis.

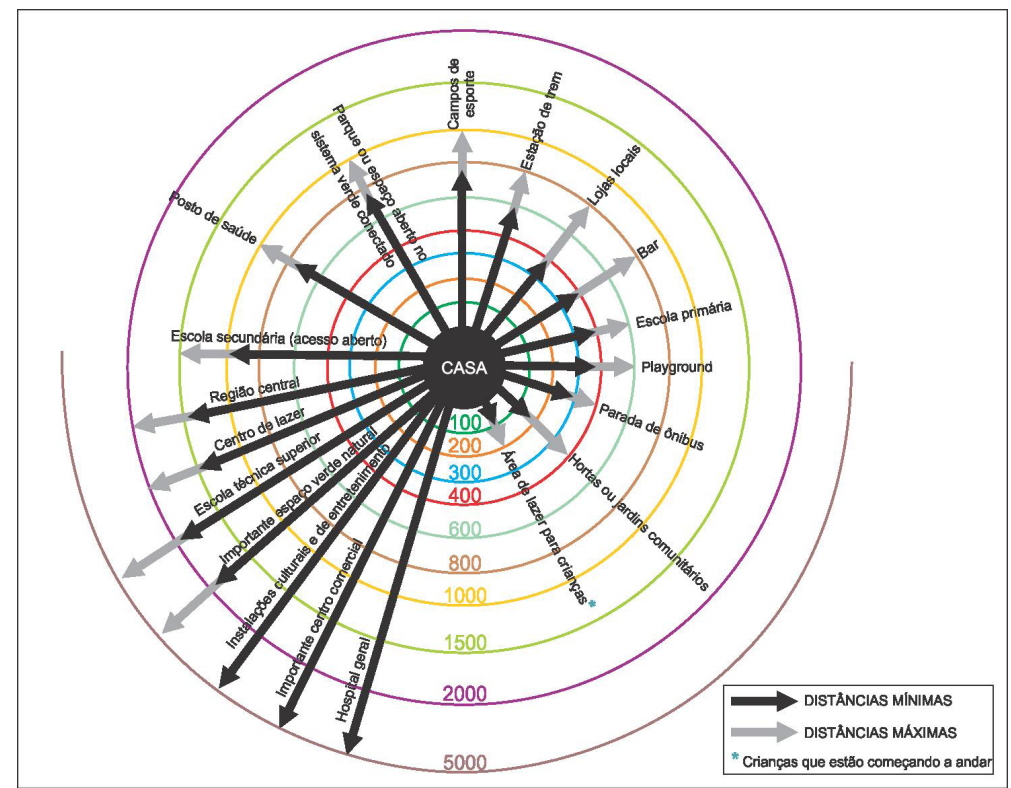

Fonte: Barton e Tsourou, 2000. Tradução e adaptação: Simone Valaski, 2011. 
Pode-se observar na figura 2 que, por exemplo, uma escola primária, deveria ser colocada entre 400 e $600 \mathrm{~m}$ de distância de cada residência, ou seja, seus usuários não deveriam andar mais de $600 \mathrm{~m}$ até a escola, por sua vez, a escola deve ficar afastada pelo menos $400 \mathrm{~m}$ das residências para que sejam evitadas as inconveniências de se viver em contato com diversos tipos de incômodos provenientes deste tipo de uso da terra.

\begin{abstract}
Ao se considerar que há uma distância mínima para separar os locais de moradia de certos usos, Barton e Tsourou (2000) inferem que esses usos, por exemplo, bares, lojas, posto de saúde, etc., podem ser considerados como potencialmente poluidores, cada qual com suas características. (TONETTI, et al., 2016, p. 38).
\end{abstract}

Portanto, a classificação dos usos conforme a sua potencialidade em aumentar ou diminuir a qualidade ambiental não é uma tarefa fácil, não somente devido às características de funcionamento de cada uso, mas também ao número enorme de usos que pode ser identificado em uma cidade. Para se ter uma ideia da complexidade da questão, uma busca nos tipos diversos de "atividades econômicas" no IBGE, foram encontradas 9.900 atividades em um relatório de 279 páginas (IBGE, 2010).

\section{Procedimentos}

O foco da pesquisa esteve voltado para a identificação do uso de cada lote dentro das quadras na zona urbana municipal, não sendo considerado o sistema viário e nem os corpos hídricos.

Por meio de pesquisa bibliográfica buscou-se elencar os critérios e parâmetros para avaliação da qualidade ambiental urbana com base no uso da terra e, tendo como principais fontes três leis municipais de uso e ocupação do solo (LUOS), sugerir uma hierarquização dos usos conforme suas potencialidades em alterar a qualidade ambiental.

Foram consultadas as LUOS dos municípios de São Paulo, Belo Horizonte e Campinas, por se tratarem de grandes municípios com uma multiplicidade de usos da terra e por estarem disponíveis na internet:

$\checkmark \quad$ Lei no 16.402, de 22/03/2016, que disciplina o parcelamento, o uso e a ocupação do solo no Município de São Paulo (SÃO PAULO, 2016).

Lei no 13.885, de 25/08/2004, Lei de Uso e Ocupação do Solo (LUOS) do Município de São Paulo (SÃO PAULO, 2004).
Decreto $n^{\circ} 45.817$, de 04/04/2005, que dispõe sobre a classificação dos usos residenciais e não residenciais. Com quadros anexos a Lei: quadro $\mathrm{n}^{\circ} 02$ (Listagem das Subcategorias de uso $n R 1, n R 2$ e $n R 3$, exceto os grupos de atividades industriais), quadro $\mathrm{n}^{\circ} 03$ (Listagem da Subcategoria de uso nR4 - Usos não residenciais compatíveis com o desenvolvimento sustentável) e quadro ${ }^{\circ} 04$ (Listagem dos grupos de atividades industriais: Ind-1a, Ind-1b, Ind-2 e Ind-3) (SÃO PAULO, 2005).

$\checkmark \quad$ Lei no 9.959, de 20/07/2010, Lei de Zoneamento. Prefeitura do Município de Belo Horizonte, DOM, Edição Especial № 78, de 21/07/2010 (BELO HORIZONTE, 2010).

Lei de Uso e Ocupação do Solo do município de Campinas. $4^{\circ}$. Edição de atualização, 2011; concluída em março/2011 (CAMPINAS, 2011).

Também foram pesquisados os seguintes objetos legais sobre o uso industrial:

Lei no 1.817, de 27/10/1978, que estabelece os objetivos e as diretrizes para o desenvolvimento industrial metropolitano e disciplina o zoneamento industrial, a localização, a classificação e o licenciamento de estabelecimentos industriais na Região Metropolitano da Grande São Paulo, e dá providências correlatas (SÃO PAULO, 1978).

Deliberação CONSEMA (Gov. Est. de São Paulo, Secretaria do Meio Ambiente) Normativa 01/2014, de 23/04/2014 - 318 Reunião Ordinária do CONSEMA, que fixa tipologia para o exercício da competência municipal, no âmbito do licenciamento ambiental, dos empreendimentos e atividades de potencial impacto local, nos termos do Art. 9, inciso XIV, alínea "a", da Lei Complementar Federal 140/2011 (SÃO PAULO, 2014).

Lei Federal $n^{\circ}$ 6.803, de 2/07/1980. (Vide Lei $n^{\circ} 7.804$, de 1989), que dispõe sobre as diretrizes básicas para o zoneamento industrial nas áreas críticas de poluição, e dá outras providências (BRASIL, 1980).

As LUOS forneceram uma ideia geral do potencial para a diminuição da qualidade ambiental, pois nelas os usos de terra se encontram dispostos em zonas que apresentam, pelo menos na teoria, uma distribuição no município de modo a se evitar a incompatibilidade de usos conflitantes. 
Além do uso, também se considerou o porte dos estabelecimentos na proposta de hierarquização, tendo como base a LUOS do município de São Paulo (SÃO PAULO, 2016). No quadro 1 são encontrados alguns exemplos de usos e seus portes, que serviram como referencial geral na construção da legenda proposta, já que não se encontrou essa proposição para todos os usos existentes nessa lei.
Após a hierarquização, os usos foram relacionados, de forma comparativa entre si, com índices de qualidade ambiental, de acordo com as inferências possíveis sobre as suas dinâmicas e sua capacidade de aumentar ou diminuir a qualidade ambiental.

Quadro 1 - Exemplos de usos, dimensões e seus impactos em relação a vizinhança residencial, conforme LUOS do município de São Paulo (SÃO PAULO, 2016). Org.: os autores, 2017.

\begin{tabular}{|c|c|c|}
\hline Uso & Dimensões (porte) & $\begin{array}{l}\text { Situação em relação a } \\
\text { vizinhança residencial }\end{array}$ \\
\hline \multirow{3}{*}{$\begin{array}{l}\text { Comércio de } \\
\text { alimentação }\end{array}$} & $<100$ lugares (pequeno) & Compativel \\
\hline & $\begin{array}{l}100 \text { a } 500 \text { lugares } \\
\text { (médio) }\end{array}$ & Tolerável \\
\hline & $>500$ lugares (grande) & Incômodo \\
\hline \multirow{3}{*}{$\begin{array}{l}\text { Comércio de } \\
\text { abastecimento }\end{array}$} & $<500 \mathrm{~m}^{2}$ & Compatível \\
\hline & $500 \mathrm{~m}^{2}$ a $2.000 \mathrm{~m}^{2}$ & Tolerável \\
\hline & $>2.000 \mathrm{~m}^{2}$ & Incômodo \\
\hline \multirow{2}{*}{$\begin{array}{l}\text { Estabelecimentos de } \\
\text { ensino }\end{array}$} & $<2.500 \mathrm{~m}^{2}$ & Tolerável \\
\hline & $>2.500 \mathrm{~m}^{2}$ & Incômodo \\
\hline \multirow{2}{*}{ Serviços de saúde } & $<7.500 \mathrm{~m}^{2}$ & Tolerável \\
\hline & $>7.500 \mathrm{~m}^{2}$ & Incômodo \\
\hline
\end{tabular}

\section{Resultados e discussão}

Dos documentos legais consultados, considerando o uso da terra, o porte dos estabelecimentos e a inferência da dinâmica, estruturou-se a proposta de legenda, apresentada na figura 3 no formato de um quadro resumo com a hierarquização dos tipos de uso de acordo com a potencialidade de aumento ou diminuição da qualidade ambiental, como uma proposta de legenda para o mapeamento em escalas de detalhe. A organização dos usos na figura 3 é o resultado de uma síntese dos usos encontrados nas LUOS analisadas e que podem ser consultados no Anexo 1 deste artigo. 
Figura 3 - Proposta de legenda para a correlação entre usos da terra e qualidade ambiental.

\begin{tabular}{|c|c|c|}
\hline & Índice & Usos \\
\hline \multirow{4}{*}{ 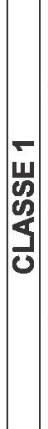 } & $Q A+1$ & $\begin{array}{c}\text { Conservação da natureza e recreação } \\
\text { em contato com a natureza }\end{array}$ \\
\hline & QA 0 & $\begin{array}{l}\text { Recreação e salvaguarda de bens de } \\
\text { valor histórico, artístico, arquitetônico, } \\
\text { arqueológico e paisagístico }\end{array}$ \\
\hline & QA -1 & $\begin{array}{l}\text { Recreação e salvaguarda de bens de } \\
\text { valor histórico, artístico, arquitetônico, } \\
\text { arqueológico e paisagístico }\end{array}$ \\
\hline & QA -2 & $\begin{array}{l}\text { Atividades econômicas compatíveis com } \\
\text { a manutençăo e recuperação dos } \\
\text { serviços ambientais }\end{array}$ \\
\hline
\end{tabular}

\begin{tabular}{|c|}
\hline Exemplo \\
\hline Unidades de Conservação, parques e bosques urbanos \\
\hline $\begin{array}{c}\text { Espaços livres de edificação: praças, jardins, playground, } \\
\text { terreno baldio }\end{array}$ \\
\hline
\end{tabular}

Espaços edificados como clubes esportivos sociais, de campo e náuticos

Pesquisa, manejo e educação ambiental, captação e água mineral

\begin{tabular}{|l|l|c|}
\hline QA -3 & Residencial unifamiliar \\
\hline \hline QA -4 & Conjunto residencial \\
\hline & QA -5 & $\begin{array}{r}\text { Serviço de pequeno porte com lotação } \\
\text { de até } 100 \text { pessoas }\end{array}$ \\
\hline Q & $\begin{array}{c}\text { Serviço e comércio de pequeno porte. } \\
\text { Máximos: } 1.500 \mathrm{~m}^{2} \text { de área construída, } \\
100 \text { lugares, } 40 \text { vagas de estacionamento }\end{array}$ \\
\hline
\end{tabular}

\begin{tabular}{|c|c|}
\hline QA -7 & $\begin{array}{l}\text { Serviço e comércio de médio porte. } \\
\text { Máximos: } 7.500 \mathrm{~m}^{2}, 500 \text { lugares. }\end{array}$ \\
\hline QA -8 & $\begin{array}{l}\text { Serviço e comércio de grande porte. } \\
\text { Acima de } 7.500 \mathrm{~m}^{2} \text { e de } 500 \text { lugares. }\end{array}$ \\
\hline QA -9 & $\begin{array}{l}\text { Serviços e comércio de grande porte. } \\
\text { (acima de } 7.500 \mathrm{~m}^{2} \text {, mais de } 500 \text { lugares, } \\
200 \text { vagas de estacionamento) e oficinas. }\end{array}$ \\
\hline
\end{tabular}

Asilo, estabelecimento de ensino, delegacia de polícia, local de reunião, academia, clube, comércio de alimentos, serviços de saúde, autoescola

Universidades, serviços de saúde, local de reunião, local de culto, supermercado

Garagem de ônibus, caminhões e de máquinas, aluguel de veículos, centro de inspeção, penitenciária, quartéis, quadra de escola de samba, terminal rodoviário, estações de metrô e de trem. Mecânica em geral e ferro velho

\begin{tabular}{|l|l|l|}
\hline QA -10 & Atividade industrial nível 1 \\
\hline & QA -11 & Atividade industrial nível 2 \\
\hline QA -12 & & Atividade industrial nível 3 \\
\hline QA -13 & Atividade industrial nível 4 \\
\hline Q & & \\
\hline
\end{tabular}

Fabricação de artigos de vestuário, de artefatos de papel, de máquinas para escritório, equipamentos de informática. Lavanderia hospitalar, marcenaria, serralheria, gráfica, posto de combustiveis, funilaria, aeroportos e helipontos

Fabricação de produtos alimentícios e bebidas; de produtos têxteis (sem operaçōes de fiação, tecelagem, beneficiamento e tingimento), de artefatos de couro, de produtos de plástico, madeira, palha, cortiça e bambu

Fabricação de conservas, produtos de cereais, refino de óleos. Automobilística. Extração de carvão, petróleo. Gestão de resíduos sólidos, ETA e ETE. Depósito de inflamáveis. Comércio de fogos de artifício. Cemitérios

Fabricação de óleos, rações, celulose. Curtimento. Fabricação de coque, refino de petróleo, intermediários para fertilizantes, resinas e fibras. Fabricação de explosivos, solventes, cimento, cal, telhas, produção de gusa, ferro e aço

Org.: os autores, 2017. 
$\mathrm{Na}$ proposta de legenda, os usos foram agrupados em 4 classes e em 15 níveis de qualidade ambiental, conforme as características de uso, propriamente dita, e o porte do estabelecimento (FIGURA 3).

A classe 1 apresenta usos relacionados com a preservação e conservação da natureza e recreação em contato com a natureza, onde a vegetação e os corpos hídricos são elementos importantes desses espaços, contribuindo para a melhoria da qualidade ambiental $(Q A+1)$, recebendo na legenda a cor verde escura para enfatizar a importância da vegetação e dos espaços livres de edificação na cidade. Já os usos como praças (sem ou com pouca vegetação), playground, entre outros foram categorizados como neutros em relação à qualidade ambiental (QA 0). Os clubes de campo e atividades econômicas compatíveis com os serviços ambientais que elas fornecem, por já contarem com um pouco mais de edificações e por suas características de utilização, apesar da existência de espaços vegetados, foram inseridos como os primeiros usos que colaboram com a diminuição da qualidade ambiental ( $Q A$-1 e QA -2 , respectivamente), recebendo na legenda tons de verde mais claros, tendendo para o amarelo.

$\mathrm{Na}$ classe 2 encontram-se os usos residenciais e alguns serviços de suporte diário para os moradores. 0 uso residencial ainda foi subdividido em dois níveis conforme o número de pavimentos (QA -3 e QA -4). 0 uso serviços, nesta classe, foi subdividido em dois níveis (QA -5 e QA -6), pois há vários tipos de usos no nível QA -6 que podem ocasionar maior incômodo e diminuição da qualidade ambiental, se comparado com o uso anterior, tais como central de armazenamento e distribuição de cargas, armazém, mercearia, casa de carnes (açougue, avícola, peixaria), padaria, bar, casas de música, salão de festas, entre outros. Os tons de amarelo e a tendência para o vermelho, ou seja, cores um pouco mais "quentes" em relação aos tons de verde, indicam um aumento da capacidade de diminuir a qualidade ambiental.

$\mathrm{Na}$ classe 3 encontram-se dois níveis de comércio e serviços separados pelo porte dos estabelecimentos (QA -7 e QA -8) e um terceiro nível com comércio e serviços de grande porte, além das oficinas (QA -9). As cores da legenda apresentam tons de vermelho chegando ao marrom, indicando uma classe que muito pode contribuir com a diminuição da qualidade ambiental.

$\mathrm{Na}$ classe 4 foram incluídos os usos industriais, com níveis de potencialidade para diminuir a qualidade ambiental indo de 10 (QA - 10) ao máximo de 13 (QA -13). Os diferentes tipos de indústrias foram hierarquizados conforme os processos envolvidos em suas plantas e que podem ocasionar impactos ambientais negativos, tais como níveis de ruído, de vibração e de outros tipos de poluição ambiental, além de fluxos de veículos de carga e descarga, entre outros e de pessoas. Para essa classe foram selecionados tons de cinza culminando com o preto. Na cor preta estão as "indústrias de altíssimo potencial poluidor, as quais não devem, jamais, situarem-se em áreas urbanas, exemplos: produção de cimento, siderúrgicas, refinarias de petróleo" (MOTA, 1999, p. 220).

Os usos mais consensuais em relação as suas capacidades em alterar a qualidade ambiental se encontram nos extremos da legenda: parques e indústrias. (FIGURA 3).

Os usos relacionados com a preservação ou conservação da natureza e recreação em contato com a natureza foram selecionados como os únicos no meio urbano capazes de aumentar a qualidade ambiental. Parques urbanos, em termos gerais, fornecem serviços ecossistêmicos que trazem benefícios direto aos seres humanos. A vegetação desses espaços pode fornecer água, alimento, combustíveis e remédios; regula inundações, poluição, erosão do solo e o clima; promove serviços culturais como benefícios espirituais, estéticos, recreativos e educacionais; aumenta a qualidade de vida e o valor das propriedades (FRANCIS; CHADWICK, 2013, p. 55).

E, no outro extremo da legenda, os usos industriais que geralmente contribuem para a diminuição da qualidade ambiental urbana. Nas palavras de Francis e Chadwick (2013, p. 53), esses usos provocariam "desserviços ecossistêmicos", ou seja, processos ecossistêmicos que têm um efeito negativo no bem-estar humano, como aumento dos poluentes e das doenças em vários ambientes sensíveis e nas pessoas.

Os usos industriais estão bem caracterizados de acordo com sua capacidade geradora de poluição e de conflitos devido às pesquisas científicas e técnicas internacionais e nacionais já desenvolvidas, o que forneceu base para a elaboração de uma legislação própria que instrui o afastamento desses usos do convívio urbano. Assim, os usos industriais foram inseridos na legenda como aqueles que mais contribuem com a diminuição da qualidade ambiental urbana e a hierarquia entre eles é facilmente identificada nas LUOS e em leis federais e estaduais.

Chama a atenção, dentre os usos industriais, o uso "cemitério". Apesar de que, em diversas situações no exterior e em algumas no Brasil, os cemitérios possam contribuir com serviços ecossistêmicos (FORMAN, 2014, p. 357), para Kemerich, et al. (2016): 
Cemitérios são áreas que geram alterações no meio físico e por isso devem ser considerados fontes sérias de impacto ambiental (...). Diversos estudos de natureza ambiental associam áreas que abrigam cemitérios a aterros sanitários, considerando que em ambos estão disponíveis materiais orgânicos e inorgânicos com potencial contaminante. Mas, no caso de cemitérios, esses resíduos podem estar associados a um número ainda maior de patógenos, com potencial de levar à morte pessoas eventualmente contaminadas por eles. (KEMERICH, et al., 2016, p. 1).

Assim, tirando esses extremos na legenda proposta, os outros usos foram hierarquizados conforme as distribuições das zonas encontradas nas LUOS e também por meio de inferências sobre a potencialidade de cada uso diminuir a qualidade ambiental, seja alterando as condições atmosféricas, hídricas, do solo e sonoras.

$\mathrm{Na}$ revisão bibliográfica comentou-se sobre a necessidade de se identificar os usos de boa e de má vizinhança na zona urbana. Nas LUOS analisadas aparecem termos como "uso compatível com a vizinhança residencial", "uso tolerável com a vizinhança residencial", "uso incômodo à vizinhança residencial". Todavia, excetuando-se os usos que se encontram no alto da legenda, tais como parques e praças, todos os outros, de uma forma ou de outra, inclusive o residencial, apresentam alguma potencialidade para diminuir a qualidade ambiental, devido às atividades que exercem nos lotes e quadras, exigindo entrada (input) de recursos (energia e materiais), que chegam aos lotes por diferentes meios, inclusive por veículos poluentes, passam por transformações no seu interior e emitem (output) diversos tipos de poluentes para as águas, para o solo e para o ar, que acabam prejudicando a qualidade ambiental. Segundo Mota (1999, p. 183), "as principais fontes localizadas de poluição da água superficial são os lançamentos de esgotos domésticos e industriais".

Considerando-se o disco das distâncias proposto por Barton e Tsourou (2000), figura 2, até mesmo um parque não deveria estar ao lado do uso residencial, sendo que os autores sugerem uma distância mínima de $700 \mathrm{~m}$ e máxima de $1.000 \mathrm{~m}$ entre o parque e a residência.

A mistura de usos permitida nas LUOS é prejudicial. Observou-se, por exemplo, que o nível de qualidade ambiental -11 (QA -11), na figura 3, contém atividades, como fabricação de sorvetes, produtos de padaria, confeitaria, produção de derivados do cacau; fabricação de artefatos de tapeçaria e de cordoaria, de tecidos de malha, de aviamentos para costura, de meias, de artefatos de couro, produtos de plástico, produtos de madeira, peças e acessórios de veículos, móveis, etc, que se enquadram em atividade industrial incômoda, mas compatível com a vizinhança residencial, ou seja, assume-se que haverá mesmo usos incômodos próximos ao uso residencial.

Como exemplos de uso incômodo à vizinhança residencial, determinado pela legislação, tem-se venda ou guarda de máquinas ou equipamentos, guarda de móveis ou animais, incluindo garagem de ônibus, acima de $5.000 \mathrm{~m}^{2}$, estacionamentos com mais de 200 vagas; comércio de veículos automotores e seus acessórios, peças e equipamentos, ferro velho, etc. Porém, apesar de serem incômodos à vizinhança, permite-se a mistura com o uso residencial em algumas zonas de acordo com as LUOS analisadas.

Pode-se inferir que mesmo os usos considerados compatíveis com a vizinhança residencial, segundo as LUOS, classificados como QA -5 (figura 3), tais como bibliotecas, estabelecimentos destinados à educação e cuidados infantis ou de alunos com necessidades especiais, unidades de saúde e assistência social de âmbito local (ambulatório, laboratório de análises clínicas - dentária, médica, veterinária), agências de correios, cartórios, consulados, Delegacia de Ensino, Órgãos da Administração Pública, Posto Policial, Serviço Funerário, entre outros, também podem exercer influência ambiental negativa, só por serem polos geradores de tráfego.

Nucci (1996), ao analisar a Lei Geral do Zoneamento, no 7.805/72, do município de São Paulo, concluiu que a mesma não foi uma proposta de melhoria das condições de vida da população, mas apenas transformou em lei a tendência já instalada da distribuição dos usos no município, privilegiando as áreas que já eram residenciais, sem mistura com outros usos, com o zoneamento $\mathrm{Z1}$ (áreas estritamente residenciais). Nas outras zonas, como Z2, Z3, Z4, Z5 e nos corredores (Z8), a lei permitia a mistura do uso residencial com casas de música, boate, shopping center, venda de peças e acessórios para automóvel, venda de motos, automóveis e caminhões, ferro velho, depósito de álcool, gás, inseticidas, óleos combustíveis, tintas; carpintaria, funilaria, gráfica, marcenaria, mecânicas e serralheria. Nucci (1996) afirma que a Lei Geral do Zoneamento de 1972 legalizou uma mistura de usos incompatíveis. Não é propósito deste trabalho discutir se as LUOS estão corretas ou não, pois aqui elas serviram apenas para fornecer um ponto de partida para a hierarquização dos usos da terra. Todavia, pelo que foi analisado, da lei de 1972 até a lei de 2016, que disciplinam o parcelamento, o uso e a ocupação do solo no Município de São Paulo, se passaram 44 anos sem que o problema da mistura de usos incompatíveis fosse solucionado. 
Outro termo comum encontrado nas LUOS seria "predominantemente". Estêvez e Nucci (2015) colocam que:

\begin{abstract}
Ao definir uma área como predominantemente industrial significa dizer que o uso mais expressivo é o da indústria. A palavra "predominantemente" dá a ideia de que a maioria dos usos é o industrial, mas que podem ocorrer outros associados, como possivelmente o residencial. (...) é possível concluir que a população residente deverá se adaptar ao nível de ruídos pois a área é definida com o predomínio da atividade industrial. É difícil definir parâmetros e delimitar áreas quando a cidade é constituída por usos incompatíveis e inconvenientes. (ESTÊVEZ; NUCCl, 2015, p. 38).
\end{abstract}

Assim, se a mistura de usos nas cidades, defendida por muitos, concentrando residências, serviços, comércio e alguns tipos de usos industriais em uma mesma área, pode trazer maior dinâmica social e econômica para as ruas, por outro lado também acarreta em uma diminuição da qualidade ambiental. Esse é um dos motivos para não se confundir qualidade de vida com qualidade ambiental. Nem sempre um aumento da qualidade de vida é acompanhado por um aumento da qualidade ambiental. No caso da mistura de usos incompatíveis o ganho de qualidade de vida é acompanhado pela perda em qualidade ambiental. 0 que se deseja, em termos de ordenamento da paisagem, vai depender dos valores da comunidade envolvida e a decisão passa a ser política e não mais científica.

\section{Conclusão}

As LUOS priorizam algumas áreas dos municípios com zonas exclusivamente residenciais e permitem que em outras áreas haja mistura de usos que as mesmas consideram compatíveis. Os usos considerados pelas LUOS como toleráveis em relação aos locais de moradia também se apresentam misturados e até, em algumas situações, usos considerados incômodos pelas LUOS são permitidos de forma misturada com outros usos considerados sensíveis. Em todo caso, a distribuição dos usos da terra em zonas, de acordo com vários e complexos critérios e parâmetros utilizados pelas LUOS, permitiu que se fizessem inferências quanto à potencialidade em aumentar ou diminuir a qualidade ambiental de acordo com cada uso da terra.

Assim, as análises das LUOS, entre outras, possibilitaram a construção de uma proposta de hierarquização dos usos da terra, localizados em zona urbana municipal, que foram organizados em um quadro legenda constituído por 4 classes e 15 níveis de qualidade ambiental, conforme as características de uso e o porte do estabelecimento, com cores variando do verde ao vermelho e, para os usos industriais foram aplicados tons de cinza, o que proporciona ao usuário a sensação de intensidade.

Os estudos baseados na teoria do Planejamento da Paisagem devem ser feitos em diversas escalas, desde 1:500.000 até 1:1.000. Para o propósito de aplicação da legenda proposta, as escalas recomendadas são aquelas que permitem a visualização e o mapeamento de cada lote, ou seja, escalas entre 1:3.000 e 1:5.000, com imprescindível verificação em campo.

O estudo da paisagem representa um campo de grandecomplexidade, tanto teórica quanto metodológica, mas esta complexidade não deve ser considerada uma barreira intransponível para o desenvolvimento de pesquisas e tentativas no sentido de se "traduzir" as interações que ocorrem entre a estrutura e a dinâmica na paisagem.

Os autores citados na revisão bibliográfica comprovam a necessidade de se entender a relação existente entre a estrutura e a dinâmica da paisagem, por meio de pesquisas básicas e aplicadas que possam subsidiar o planejamento e desenvolvimento das paisagens.

Acrescenta-se que o Planejamento da Paisagem seria mais eficiente se elaborado com a participação democrática da população. Entretanto, uma participação efetiva só pode ocorrer se a população tiver acesso à informação e possibilidades de interpretá-la, mas transformar o entendimento científico da paisagem em bases de fácil acesso e entendimento pela população ainda é uma lacuna que precisa ser preenchida.

Sendo assim, acredita-se que a inferência da dinâmica da paisagem com base em sua estrutura (uso e cobertura da terra) configura-se como um primeiro passo no sentido de se "traduzir" o seu funcionamento e de transformar essas questões em informações acessíveis à população. 


\section{Referências}

ALBERTI, M. (2008) Advances in urban ecology. University of Washington, Seattle, Washington, USA: Springer, 366p.

BARTON, H.; TSOUROU, C. (2000) Health urban planning. A WHO guide to planning for people. Londres: Spon Press (em nome da Organização Mundial da Saúde - WHO), 184p.

BELO HORIZONTE (Município). (2010) Prefeitura do Município de Belo Horizonte. Lei no 9.959, de 20 de julho de 2010 (Lei de Zoneamento). D.O.M., Edição Especial n. 78, de 21/07/2010.

BERKE, F. R.; GODSCHALK, D. R.; KAISER, E. J. RODRIGUEZ, D. A. (2006) Urban land use planning. Chicago: University of Illinois, 490p.

BRASIL. (1980) Lei Federal $n^{\circ}$ 6.803, de 02 de julho de 1980. (Vide Lei $n^{\circ} 7.804$, de 1989), (Zoneamento industrial nas áreas críticas de poluição).

BRASIL. (2001) Lei Federal n 10.257, de 10 de julho de 2001. Estatuto da Cidade. Disponível em: <www.planalto.gov. br/ccivil_03/Leis?LEIS_2001/L 10257.htm>. Acesso em: 10/02/2017.

BRASIL. (2006) Ministério das Cidades. Plano Diretor Participativo. Disponível em: <www.cidades.gov.br/ planodiretorparticipativo>. Acesso em: 24 fev. 2011.

CADENASSO, M. L.; PICKETT, S. T. A.; SCHWARZ K. (2007) Spatial heterogeneity in urban ecosystems: reconceptualizing land cover and a framework for classification. Front Ecol Environ, Washington, v. 5, n. 2, p. 80-88.

CAMPINAS (Município). (2011) Prefeitura do Município de Campinas. Lei de Uso e Ocupação do Solo do município de Campinas. $4^{\circ}$. Edição de atualização. Disponível em: <http://www.campinas.sp.gov.br/governo/seplama>. Acesso em: 15 jan. 2017.

ESTÊVEZ, L. F.; NUCCI, J. C. (2015) A questão ecológica urbana e a qualidade ambiental urbana. Geografar, v.10, n.1, p. 26-49.

FORMAN, R. T. T. (2014) Urban Ecology. Science of Cities.New York: Cambridge University Press, 462p.

FRANCIS, R. A.; CHADWICK, M. A. (2013) Urban Ecosystems. Understanding the Human Environment. New York: Routledge, 220p.

GILL, S.; HANDLEY, J.; PAULEIT, S.; ENNOS, R.; THEURAY, N.; LINDLEY, S. (2008) Characterising the urban environment of UK cities and towns: a template for landscape planning in a changing climate. Landscape and Urban Planning $\mathrm{n}$. 87 , p. 210-22.

HAAREN, C. v.; GALLER, C.; OTT, S. (2008) Landscape planning. The basis of sustainable landscape development. Leipzig: Gebr. Klingenberg Buchkunst $-\mathrm{GmbH}$. Federal Agency for Nature Conservation. Federal Agency for Nature Conservation, Field Office Leipzig. Disponível em: <http://www.bfn.de/fileadmin/MDB/documents/themen/ landschaftsplanung/landscape_planning_basis.pdf>. Acesso em: 13 out. 2013.

HOUGH, M. (1998) Naturaleza y ciudad. Planificación y procesos ecológicos. Barcelona: Gustavo Gilli, 315p.

IBGE. (2010) Proyecto de Cooperación CE - MERCOSUR en Materia de Estadística II. Grupo de Trabajo 7 - Clasificaciones y Nomenclaturas. Clasificación de Actividades Económicas Mercosur - CAEM. Disponível em: <http://www.ibge.gov. br/mercosur/2008/caem_clasificacion_de_actividades_economicas_mercosur_19102010.pdf>. Acesso: 15 dez. 2016.

KEMERICH, P.; UCKER, F. E.; BORBA, W. F. (2016) Cemitérios como Fonte de Contaminação Ambiental. Site Scientific American Brasil, Editora: Segmento. Disponível em: <http://www2.uol.com.br/sciam/artigos/cemiterios_como_fonte_ de_contaminacao_ambiental.html>. Acesso em: 24 mar. 2017

MARSH, W. M. (1997) Landscape planning. Environmental Applications. 3. Ed. New York: John Wiley \& Sons, Inc., 434p. MONTEIRO, C. A. de F. (2000) Geossistemas: a história de uma procura. São Paulo: Contexto, 127p. 
MOTA, S. (1999) Urbanização e meio ambiente. Rio de Janeiro: ABES (Associação Brasileira de Engenharia Sanitária e Ambiental, 352p.

NUCCI, J. C. (1996) Qualidade ambiental e adensamento: um estudo de Planejamento da Paisagem do distrito de Santa Cecília (MSP). 229 f. Tese (Doutorado em Geografia Física) - Programa de Pós-Graduação em Geografia Física. Universidade de São Paulo, São Paulo.

$\mathrm{NUCCI}$, J. C. (2008) Qualidade ambiental e adensamento urbano: um estudo de ecologia e planejamento da paisagem aplicado ao distrito de Santa Cecília (MSP). Curitiba: Ed. do Autor. (e-book). Disponível em: <http://www.geografia. ufpr.br/laboratorios/labs>. Acesso em: 19 jun. 2016.

NUCCI, J. C.; FERREIRA, M. B. P.; VALASKI, S. (2014) Cobertura do solo e qualidade ambiental urbana como subsídios ao Planejamento da Paisagem. In: CONGRESSO IBERO-AMERICANO DE ESTUDOS TERRITORIAIS E AMBIENTAIS, 6. 2014, São Paulo. Anais... São Paulo: CIETA, p. 2886 - 2902.

PAULEIT, S.; DUHME, F. (2000) Assessing the environmental performance of land cover types for urban planning. Landscape and Urban Planning v. 52, n. 1, p. 1-20.

PAULEIT, S.; BREUSTE, J. H. (2011) Land-Use and Surface-Cover as Urban Ecological Indicators. In: NIEMELÄ, JARI (Org.). Urban Ecology. Patterns, processes and applications. New York: Oxford University Press, 374p.

SÃO PAULO (Estado). (1978) Lei $n^{\circ}$ 1.817, de 27 de outubro de 1978, (Zoneamento industrial, classificação e licenciamento de estabelecimentos industriais na Região Metropolitano da Grande São Paulo), São Paulo.

SÃo PAULO (Município). (2004) Lei nº 13.885, de 25 de agosto de 2004 (Lei de Uso e Ocupação do Solo do Município de São Paulo), São Paulo.

SÃO PAULO (Município). (2005) Decreto n 45.817, de 04 de abril de 2005 (Classificação dos usos residenciais e não residenciais), São Paulo.

SÃO PAULO (Estado). (2014) Secretaria do Meio Ambiente. Deliberação CONSEMA. Normativa 01/2014, de 23 de abril de 2014 (Licenciamento ambiental, dos empreendimentos e atividades de potencial impacto local), São Paulo.

SÃo PAULO (Município). (2016) Lei n 16.402, de 22 de março de 2016 (Parcelamento, uso e ocupação do solo no município), São Paulo.

SOUZA, M. L. de. (2002) Mudar a Cidade. Uma introdução crítica ao planejamento e à gestão urbanos. Rio de Janeiro: Bertrand Brasil, 560p.

TONETTI, E. L.; NUCCI, J. C.; VALASKI, S. (2016) Espacialização de áreas potencialmente poluídas: proximidade de usos incompatíveis no município de Paranaguá-PR. Revista Nacional de Gerenciamento de Cidades, v. 04, n. 25, p. 33-50.

VALASKI, S. (2013) Estrutura e dinâmica da paisagem: subsídios para a participação popular no desenvolvimento urbano do município de Curitiba-PR. 148 f. Tese (Doutorado em Geografia) - Departamento de Geografia, Universidade Federal do Paraná, Curitiba. 
ANEXO 1: Proposta de hierarquização de usos da terra para determinação da qualidade ambiental urbana

QA = + 1 (Qualidade Ambiental = + 1) - Preservação e conservação da natureza, pesquisa, ecoturismo, educação ambiental e recreação em contato com a natureza. Exemplos: Unidades de Conservação da Natureza, tais como parques urbanos destinados à conservação do patrimônio ambiental e ao lazer.

QA = 0 - Espaços livres de edificação destinados à recreação ativa e passiva; valorização e salvaguarda dos bens de valor histórico, artístico, arquitetônico, arqueológico e paisagístico. Ex.: praças, jardins, terrenos baldios.

QA = - 1 - Espaços edificados destinados à preservação, valorização e salvaguarda dos bens de valor histórico, artístico, arquitetônico, arqueológico e paisagístico e espaços públicos ou privados ocupados por clubes esportivos sociais; clubes de campo e clubes náuticos.

QA = - 2 - Atividades econômicas compatíveis com a manutenção e recuperação dos serviços ambientais por elas prestados, em especial os relacionados às cadeias produtivas da agricultura e do turismo, de densidades demográfica e construtiva baixas. Ex.: atividades de pesquisa e educação ambiental, atividades de manejo sustentável (agroindústria, atividades agroflorestais, agropecuária, dentre outras); captação de água mineral/potável de mesa.

QA = - 3 - Residencial: edificações de até 4 pavimentos.

QA = - 4 - Residencial: conjunto residencial acima de 4 pavimentos.

$Q A=-5$ (serviços de pequeno porte / lotação de até 100 pessoas) - Serviço público social de pequeno porte, local de reunião ou de eventos com lotação de até 100 pessoas; prestação de serviços pessoais e profissionais (liberais, técnicos ou universitários ou de apoio ao uso residencial) de âmbito local, serviços de administração e públicos. Ex.: bibliotecas, estabelecimentos destinados à educação e cuidados infantis ou de alunos com necessidades especiais, unidades de saúde e assistência social de âmbito local (ambulatório, laboratório de análises clínicas - dentária, médica, veterinária), eletroterapia, "home care", agências de correios, telefônicas, cartórios, consulados, Delegacia de Ensino, Órgãos da Administração Pública federal, estadual e municipal, Posto Policial, Serviço Funerário entre outros; cabeleireiros e outros tratamentos de beleza, caixas bancárias automáticas, fotografia, lavanderias e tinturarias (não industriais), locação de fitas de vídeo, dvds, livros, etc.; escritórios, consultórios e agências de representação de negócios em geral, agência bancária, agência de empregos, de entregas de encomendas, de passagens e turismo, imobiliária, escritórios em geral, copiadoras, manutenção predial (eletricista, encanador, pedreiro, pintor, chaveiro, vidraceiro, jardineiro), costureiro, conservação, reparação e manutenção, limpeza e reparos de máquinas e de aparelhos eletrodomésticos, elétricos e eletrônicos de uso domiciliar, e de outros objetos pessoais e domésticos (bicicletas, brinquedos, canetas, cutelarias e outros), sapateiro, confecção de carimbos, maquetes e molduras, laboratório de Prótese Dentária, lapidação, oficinas de joias e relógios, ensino pré-escolar ou à prestação de serviços de apoio aos estabelecimentos de ensino seriado e não seriado, associações comunitárias, culturais e esportivas, casas de repouso, conventos, seminários, flats, hotéis, motéis, pensionatos, etc.

$\mathrm{QA}=-\mathbf{6}$ (serviços e comércio de pequeno porte, até $1.500 \mathrm{~m} 2$ de área construída, até 100 lugares, até 40 vagas de estacionamento) - Comércio diversificado de âmbito local; serviços de saúde (sem unidade de pronto atendimento), central de armazenamento e distribuição de cargas, serviços de armazenamento e guarda de bens móveis. Ex.: armazém, mercearia, casa de carnes (açougue, avícola, peixaria), casa de massas, confecção e comercialização de alimento congelado ou comida preparada, padaria, bar, lanchonete, sorveteria, restaurantes, casas de música, salão de festas, bailes, "buffet", aluguel de vestimentas, louças, toalhas, móveis, máquinas etc.; depósitos de material, máquinas e equipamentos em geral, distribuidora de alimentos embalados ou enlatados, de bebidas, guarda e adestramento de animais, leiloeiro oficial, depósito de madeireira, serviço de aluguel equipamento, local de culto.

QA = - 7 (serviços e comércio de médio porte, até $7.500 \mathrm{~m} 2$, de 100 a 500 pessoas) - Serviços de ensino, saúde, lazer, esportes, serviços públicos, comércio de alimentação e de abastecimento. Ex.: ensino fundamental, médio e superior, ensino complementar aos cursos profissionalizantes ou de aperfeiçoamento ou à educação informal em geral, estabelecimentos de saúde e assistência social de âmbito regional; hospitais, pronto-socorro; albergue, asilo, berçário, dispensário, telecentros, orfanato, local de reunião ou eventos, Comando de batalhão de policiamento de trânsito, Corpo de bombeiros, Delegacia de polícia, Forum, Juizado de menores, Tribunais, academias de ginástica, bilhar, bingo, boliche, clubes associativos, diversões eletrônicas, "Lan house", "Kart indoor", "Paintball", "war game", 
parque de animais selvagens, ornamentais e de lazer, pesqueiro, pista de "skate", quadras e salões de esporte para locação, associações comunitárias, culturais e esportivas, local de culto, central telefônica e estação rádio-base.

$\mathrm{QA}=-\mathbf{8}$ (serviço e comércio de grande porte, acima de $7.500 \mathrm{~m} 2$ e de 500 pessoas) - Serviço e comércio em geral, mas de grande porte. Ex.: universidades ou outros estabelecimentos de ensino, local de reunião, evento, culto ou de alimentação, shopping center.

$Q A=-9$ (serviço e comércio de grande porte, acima de $5.000 \mathrm{~m} 2$, mais de 200 vagas de estacionamento e oficinas) - Serviços de armazenamento e guarda de bens móveis, comércio de produtos especiais, oficinas. Ex.: venda ou guarda de mercadorias em geral, máquinas ou equipamentos, guarda de móveis ou animais, incluindo garagem de ônibus, caminhões e de máquinas, edifícios-garagem, aluguel de veículos, centro de inspeção de veículos, desmanche de veículos, empresa transportadora, estacionamentos, feira de veículos, autódromo, penitenciária, quartéis, quadra de escola de samba e "Drive-in", terminal rodoviário interurbano de transporte de passageiros, terminal de ônibus urbano, estações de metrô, trem, monotrilho e demais modais de transporte público coletivo urbano, comércio de produtos agro-pecuários ou minerais (borracha natural, carvão mineral e vegetal, chifres, couro, etc); comércio de madeira bruta, de produtos químicos, adubos, fertilizantes, gomas ou resinas; ferro velho.

$\mathrm{QA}=-10$ (Atividade industrial nível 1 - sem qualquer operação de anodização, pintura e tingimento, apenas montagem) - Fabricação de artigos de vestuário e acessórios, de artefatos de papel, de equipamentos de comunicações, de máquinas para escritório e equipamentos de informática, de equipamentos de instrumentação médico-hospitalares, instrumentos de precisão e ópticos, equipamentos para automação industrial, cronômetros e relógios, de material eletrônico básico, de aparelhos e equipamentos de telefonia, radiotelefonia, televisão, rádio, informática, de produtos alimentícios e bebidas artesanais, de artigos esportivos, recreativos, de placas e cartazes, embalagem, rotulagem, encadernação e restauração de livros. Laboratório de controle tecnológico e análise química, lavanderia hospitalar, estúdio fotográfico, de gravação de vídeo, de sons, de filmagens. Soldagem, vidraçaria, cantaria, marmoraria, carpintaria, marcenaria, serralheria, gráfica, clicheria, linotipia, fotolito, litografia e tipografia. Manutenção e reparação de artefatos de metal (armeiros, ferreiros), de veículos automotores e motocicletas (alinhamento e balanceamento, amortecedores, chassis, estofamento, faróis, freios, funilaria, molas, motores, pinturas e similares), posto de abastecimento e lavagem de veículos. Abastecimento de gás natural, tais como estações de regulagem de pressão de gás e centrais de cogeração e abastecimento de água. Geração, transmissão e distribuição de energia elétrica, tais como estações e subestações reguladoras de energia elétrica e sistema de transmissão de energia elétrica, inclusive estação e subestação reguladora, usinas hidrelétricas, usinas termoelétricas, usinas eólicas, usinas fotovoltaicas, usinas de biomassa, usinas de biogás ou biometano, usinas elevatórias, barragens, diques, sangradouros e reservatórios para a geração de energia elétrica. Base aérea ou de treinamento militar; Campo para treinamento de combate contra incêndios; Central de controle de zoonoses. Transporte aéreo, tais como aeroportos, aeródromos e helipontos.

QA = - 11 (Atividade industrial nível 2 - até $1.000 \mathrm{~m}^{2}$ de área construída) - Fabricação de produtos alimentícios e bebidas (produtos de padaria, confeitaria; sorvetes; derivados do cacau e elaboração de chocolates; fabricação de gelo (usando freon como refrigerante), engarrafamento e gaseificados de águas minerais dentre outros; fabricação de produtos têxteis (sem operações de fiação, tecelagem, beneficiamento e tingimento de fibras têxteis ou tecidos); preparação de couros e fabricação de artefatos de couro, artigos de viagem e calçados (sem operações de curtimento); fabricação de produtos de plástico, de produtos de madeira, palha, cortiça e bambu. Fabricação de peças e acessórios para veículos automotores (indústrias de montagem que não envolva transformação de matéria-prima).

QA = - 12 (Atividade industrial nível 3 - potencialmente insalubres e com riscos de periculosidade) - Fabricação de produtos alimentícios e bebidas (preparação de alimentos, conservas, produtos de cereais, bebidas, refino de óleos vegetais, preparação de margarina e outras gorduras vegetais e de óleos de origem animal não comestíveis, fabricação de produtos de arroz, milho e mandioca, café e mate solúvel, dentre outros). Fabricação de produtos do fumo. Fabricação de produtos têxteis (beneficiamento e tecelagem de fibras têxteis, estamparia e texturização, alvejamento e tingimento de tecidos, dentre outros). Fabricação de papel e produtos de papel. Fabricação de álcool, cloro e álcalis, gases industriais, etc, produtos farmacêuticos, sabões e detergentes, artigos de perfumaria e cosméticos, aditivos de uso industrial, chapas, filmes e outros materiais e produtos químicos para fotografia, discos, fertilizantes fosfatados, nitrogenados e potássicos, adubos, resinas, fibras, fios, cabos e filamentos contínuos artificiais e sintéticos, defensivos 
agrícolas, produtos de limpeza e polimento, tintas, vernizes, esmaltes, lacas e produtos afins, carvão vegetal, velas, fungicidas, herbicidas, concentrados aromáticos naturais, artificiais e sintéticos. Fabricação de artigos de borracha. Fabricação de produtos de minerais não metálicos (vidro, artefatos de concreto, cimento e estuque, dentre outros). Reciclagem de sucatas não-metálicas. Metalurgia básica (produção de laminados de aço, metalurgia de diversos metais, fundição), processos de forja, galvanoplastia, usinagem, solda, têmpera, cementação e tratamento térmico de materiais. Fabricação de máquinas e equipamentos (motores, bombas, tratores, armas, eletrodomésticos, dentre outros). Fabricação de pilhas, baterias e acumuladores elétricos, lâmpadas e equipamentos de iluminação, geradores, transformadores, etc. Fabricação e montagem de veículos automotores. Indústria extrativista (extração de água mineral, carvão mineral, petróleo e gás natural, xisto, areias betuminosas, minérios, pedra, areia e argila, ardósia, granito, mármore, calcário/dolomita, gesso e caulim, areia, cascalho ou pedregulho, saibro, basalto, dentre outros. Local de eventos destinados à feira de exposição ou show de natureza social, esportiva, religiosa, lazer e agropecuária. Gestão integrada de resíduos sólidos, tais como depósito ou transbordo de materiais para reciclagem, usina ou estação de transbordo e de tratamento, aterros de resíduos sólidos. Estação de tratamento, reservatório, estação elevatória de água, estação de tratamento de esgoto, reservatório de retenção de água pluvial). Estação de controle e depósito de petróleo, estacionamento especial de veículos transportando produtos perigosos ou em situações de emergência. Depósitos de inflamáveis, combustíveis, álcool, inseticidas, lubrificantes, resinas, gomas, tintas e vernizes ou outros produtos químicos perigosos, depósito de botijões de gás, comércio e depósito de fogos de artifício e estampidos. Cemitérios.

QA = - 13 (Atividade industrial nível 4 - deve ser proibida em zona urbana) - Fabricação de produtos alimentícios: óleos, gorduras, beneficiamento de arroz, fabricação de rações balanceadas, dentre outros produtos que exigem soluções tecnológicas complexas ou onerosas para seu tratamento (preparação de carne, banha e produtos de salsicharia, pescado e conservas de peixes, crustáceos e moluscos, produção de óleos vegetais em bruto, preparação do leite, fabricação de produtos do laticínio, usinas de açúcar, fabricação de gelo (usando amônia como refrigerante); curtimento e outras preparações de couro; fabricação de celulose e pastas para fabricação de papel; fabricação de coque, refino de petróleo, elaboração de combustíveis nucleares; fabricação de asfalto; fabricação de produtos químicos (processos e operações altamente nocivas para a saúde pública e o meio ambiente): intermediários para fertilizantes, resinas e fibras, produtos petroquímicos básicos, produtos da destilação da madeira, fabricação de explosivos (pólvoras, detonantes, munição e artigos pirotécnicos), de impermeabilizantes e solventes. Fabricação de cimento, cal, telhas, tijolos, ornatos e estruturas de amianto; metalúrgica básica (produção de gusa, ferro e aço). Britamento de pedras. 